\title{
Cytotoxic Effect of Bitter Melon (Momordica charantia L.) Ethanol Extract and Its Fractions on Pancreatic Cancer Cells in vitro
}

\author{
Rebecca A. Richmond ${ }^{1 *}$, Quan V. Vuong ${ }^{2}$ and Christopher J. Scarlett ${ }^{1}$ \\ ${ }^{1}$ Pancreatic Cancer Research Group, School of Environmental \& Life Sciences, University of Newcastle, Ourimbah, NSW, Australia; \\ ${ }^{2}$ Nutrition, Food \& Health Research Group, School of Environmental \& Life Sciences, University of Newcastle, NSW, Australia
}

\begin{abstract}
Background and objectives: The incidence of pancreatic cancer (PC) closely matches mortality, with current therapies ineffective often due to late diagnosis and difficulties in drug delivery. Bitter melon (Momordica charantia, Cucurbitaceae) has been traditionally used as an herbal medicine, particularly for the treatment of diabetes, in South East Asian countries. The aim of this study was to investigate the anti-PC potential of a crude ethanol extract (CE) and its enriched fractions.

Methods: The CE was used to prepare the saponin-enriched extract (SE) using n-butanol: water extraction. CE was also used for preparation of fractions 1,2 and 3 (F1, F2 \& F3) with a semi-preparative high-pressure liquid chromatography system. Cucurbitacin B (CuB), a triterpenoid present in many Cucurbitaceae species was also investigated for its effect on PC cells. The cytotoxicity was assessed in the PC cells MiaPaCa2, BxPC3 and CFPAC-1, and normal pancreas cells (HPDE) using the Cell Counting Kit-8 viability assay. Cell cycle analysis and induction of apoptosis in cells treated with F3 or CuB was determined using the Muse ${ }^{\mathrm{TM}}$ flow cell analyzer.
\end{abstract}

Results: The CE reduced the viability of MiaPaCa2 cells without affecting the normal cells, but only at 1,000 $\mu \mathrm{g} /$ $\mathrm{mL}$. The SE reduced viability of all cells; however, the GI50 was significantly lower for the HPDE cells (72h: 72.1 $\mu \mathrm{g} / \mathrm{mL}$ HPDE vs. $350.8 \mu \mathrm{g} / \mathrm{mL}$ MiaPaCa2). F3 and CuB appeared to arrest the cell cycle at G1/0 and G2/M, respectively; however, only CuB induced apoptosis via increased expression of caspase 3/7.

Conclusions: The CE, SE and three fractions elicited a weak cytotoxic effect on PC cells. Further research into bitter melon is recommended to isolate and identify any active components in F3 and further investigate their potential as novel agents against PC.

Introduction

Pancreatic cancer (PC) is the fourth most lethal form of cancer in

Keywords: Bitter melon; Pancreatic cancer; Herbal medicine.

Abbreviations: $\mathrm{AE}$, aescin equivalent; $\mathrm{BMJ}$, bitter melon juice; CCK-8, Cell Counting Kit-8; CE, crude ethanol extract; $\mathrm{CuB}$, Cucurbitacin B; F1, fraction 1; F2, fraction 2; F3, fraction 3; FBS, fetal bovine serum; GI50, minimum $50 \%$ growth inhibitory concentration; HPDE, human pancreatic ductal epithelial; HPLC, high-pressure liquid chromatography; L-Glu, L-glutamine; PBS, phosphate-buffered saline; PC, pancreatic cancer; SE, saponin-enriched extract.

Received: September 06, 2017; Revised: November 14, 2017; Accepted: November 24, 2017

*Correspondence to: Rebecca A Richmond, Pancreatic Cancer Research Group, School of Environmental \& Life Sciences, University of Newcastle, Ourimbah, NSW, Australia. Tel: 419121535, E-mail: rebecca.richmond@uon.edu.au

How to cite this article: Richmond RA, Vuong QV, Scarlett CJ. Cytotoxic Effect of Bitter Melon (Momordica charantia L.) Ethanol Extract and Its Fractions on Pancreatic Cancer Cells in vitro. Exploratory Research and Hypothesis in Medicine 2017;2(4):139-149. doi: 10.14218/ERHM.2017.00032.
Western society, with mortality closely mirroring incidence and an overall 5-year survival of less than 7\%.1,2 Upon diagnosis, only $20 \%$ of patients are eligible for surgery, the only potential cure to date, with the remainder in advanced stages of the disease.

Surgery is invasive due to the physical location of the pancreas and is often used as a treatment option in combination with chemotherapy. Despite this, a majority of patients who undergo surgery suffer a relapse from metastatic disease or experience comorbidities such as venothromboembolic disease. ${ }^{3-5}$ Chemotherapy for PC patients involves treatment with agents such as the standard chemotherapeutic anti-metabolite drug gemcitabine (a pyrimidine analogue), or adjuvant therapy with additional agents such as the anti-tubulin agent nab-paclitaxel that can block nuclear division, causing cell death. ${ }^{3,6,7}$ Combination drug 5-fluorouracil/folinic acid, irinotecan and oxaliplatin (FOLFIRINOX) is also a common treatment option but despite better response and survival rates than with single-agent gemcitabine treatment, FOLFIRINOX has greater levels of toxicity. ${ }^{3}$ Chemotherapy outcomes are varied due to physical and genetic obstacles of PC that cause complications, as they can 
prevent or impede drug effectiveness and create chemotherapeutic resistance. ${ }^{3,8}$ These obstacles include barriers caused by the tumor microenvironment and pancreatic stem cells., ${ }^{9,10}$ Herbal medicine may hold the key to overcoming these barriers for PC sufferers.

Herbal medicine in the prevention and treatment of PC is credited with substantial advantages, such as tumor suppression, improving radio- and chemotherapy efficacies, reducing side effects from treatment, improving immune function and sensitizing cells to chemotoxins. ${ }^{11}$ Bitter melon, as an herbal remedy, has demonstrated success in a variety of ailments, particularly in the treatment of diabetes, and has also been shown to prevent proliferation and growth of cancer cells, and as such is a novel candidate in the development of a treatment for PC. To date, bitter melon extracts and some purified isolated components have been assessed in various in vitro and in vivo studies as potential cancer therapies for prostate, liver, colon and breast cancers, and has been shown to induce cell death mechanisms, promoting apoptosis.

In PC, bitter melon juice (BMJ) increased necrotic cell death in gemcitabine-resistant pancreatic adenocarcinoma cells by enhancing autophagy and inhibiting AKT, ERK1/2, PI3K and PTEN phosphorylation, molecules involved in the prevention of apoptosis and also thought to be involved in drug resistance. ${ }^{12}$ Another identified mechanism of action of BMJ in PC cells is activation of adenosine monophosphate kinase, which is an enzyme involved in cellular metabolism and the signaling pathways that suppress growth. ${ }^{13} \mathrm{In}$ $\mathrm{PC}$ cells, BMJ also induced intrinsic apoptosis by increasing levels of the pro-apoptotic molecule Bak and reducing levels of the anti-apoptotic molecules XIAP and survivin, both of the inhibitors of apoptosis protein (IAP) family, able to inhibit caspases 3/6/7.13 Bitter melon has also been linked with prevention of tumor formation and increasing life expectancy, and in reducing the size, weight, volume and proliferation of tumors in vivo for mouse and rat models of pancreatic, breast and prostate cancers. ${ }^{8,13-16}$

The extracts and juice of bitter melon contain high levels of glycosides (saponins), alkaloids, reducing sugars, resins, phenolic constituents, fixed oils and free acids. ${ }^{17,18}$ The bioactive components contributing these effects have so far been identified as ribosome inactivating proteins, other proteins (identified as MAP30, MCP30 and momordin), fatty acid alpha-eleostearic acid, and various triterpenoid compounds of the Cucurbitaceae family. The cytotoxic effect of various saponin compounds have also been explored in an array of different cancer cell lines in vitro, including colon, leukemia and breast cancers, with proposed mechanisms of action including inhibition of cell cycle signaling processes, initiation of apoptosis and degradation of the cytoskeleton. ${ }^{19-27}$ Bitter melon has potential as an anti-PC agent, inhibiting pancreatic cell growth by causing cell cycle arrest, apoptosis and reducing the metastatic potential of this disease.

Due to the high anticancer potential of saponin compounds and the additional cytotoxic effects of bitter melon extracts in various cancer cell lines, the aim of this study was to assess the anticancer activity of a saponin-enriched Big Top Medium bitter melon extract on pancreatic cell lines in vitro. There is currently no data available on the use of the Big Top Medium variety of bitter melon in this type of research, with studies favoring the Chinese or Thai varieties. Recently, Tan and colleagues reported optimized conditions for preparing an extract of Big Top Medium bitter melon with an increased saponin yield. ${ }^{28}$ The mechanisms involved in cytotoxicity against cell lines of different genetic profiles were examined as well as isolating the bioactive component/s responsible for the effects on these cells. It was hypothesized that saponin compounds from the enriched bitter melon extract are the bioactive components, which contribute to the cytotoxic action against $\mathrm{PC}$ cells in vitro and would give a greater cytotoxic effect than the crude extract.
Methods

\section{Preparation of bitter melon extracts}

Crude ethanol extract (CE) and saponin-enriched extract (SE) prepared from Big Top Medium bitter melon (Momordica charantia L.) as described by Tan and colleagues was provided by Dr. Quan V Vuong (University of Newcastle, Faculty of Science, Australia). ${ }^{28}$ The extracts were kept at $-20{ }^{\circ} \mathrm{C}$ until time of analysis. In brief, the $\mathrm{SE}$ was prepared from the $\mathrm{CE}$ by first dissolving in water $(10 \mathrm{mg} / \mathrm{mL})$ and then extracting three times $(1 / 1 \mathrm{v} / \mathrm{v})$ with water-saturated n-butanol. The SE were then combined, washed twice with deionized water and concentrated to dryness under reduced pressure (rotary evaporator at $40 \pm 2{ }^{\circ} \mathrm{C}$ ). The remaining solid was then redissolved in $50 \%$ aqueous methanol and again evaporated to dryness to obtain the saponin enriched fraction (i.e. the $\mathrm{SE}$ ).

At the time of publication, there were no commercially available saponins from the Cucurbitaceae species, and Cucurbitacin B hydrate (Catalogue Number C8499-5MG; Sigma Life Sciences, St Louis, MO, USA), a commercially prepared cucurbitane triterpenoid was used to observe the effects on PC cells. The $\mathrm{CE}$ was used to prepare three enriched fractions with a preparative highpressure liquid chromatography (HPLC) system (Shimadzu Australia, Rydalmere, NSW, Australia). The extract was dissolved in $50 \%$ methanol $(10 \mathrm{mg} / \mathrm{mL})$, filtered twice using a $0.45 \mu \mathrm{m}$ nylon membrane syringe filter, and auto-injected at $300 \mu \mathrm{L}$ with a flow rate of $3 \mathrm{~mL} / \mathrm{min}$. The column was a Synergi $4 \mathrm{u}$ Polar-RP $80 \mathrm{~A}$ column $(250 \times 10 \mathrm{~mm})$ connected to a PDA detector, scanning all wavelengths. MilliQ Water containing $0.2 \%$ formic acid was Solvent A and acetonitrile was Solvent B. Solvent B concentration increased with a linear gradient from $0-40 \%$ between 0 to 15 $\mathrm{min}$, increasing further to $100 \%$ Solvent B from $15 \mathrm{~min}$ to $25 \mathrm{~min}$, then decreasing to $0 \%$ Solvent B from 25 min to 35 min. Peaks are identified with their retention time, the first peak eluting at 9.76 $\mathrm{min}$. Three fractions were collected using an auto-collector, with the elution time for Fraction $1(\mathrm{~F} 1)=4.50-12.60 \mathrm{~min}$, Fraction 2 $(F 2)=20.30-30.00 \mathrm{~min}$ and Fraction $3(\mathrm{~F} 3)=34.20-41.80 \mathrm{~min}$ (Fig. 1). These fractions were evaporated, freeze-dried and stored at $-20{ }^{\circ} \mathrm{C}$ for further analysis.

\section{Total saponin content}

The total saponin content of CE and SE extracts was measured according to the method of Hiai and colleagues (1976) with slight modifications. For the extracts, they were diluted to $1 \mathrm{mg} / \mathrm{mL}$ dissolved in deionized water and $0.5 \mathrm{~mL}$ was mixed with $0.5 \mathrm{~mL}$ of $8 \%(\mathrm{w} / \mathrm{v})$ vanillin solution, cooled in an iced water bath and $5 \mathrm{~mL}$ of $72 \%(\mathrm{v} / \mathrm{v})$ sulphuric acid added. After $10 \mathrm{~m}$, the cooled mixture was incubated at $60^{\circ} \mathrm{C}$ for $15 \mathrm{~m}$ and then cooled on ice for a further $10 \mathrm{~m}$. The absorption of the mixture was measured at 560 nm using a spectrophotometer (Cary 60 Bio; Varian Pty. Ltd., Mulgrave, Vic, Australia) against a reagent blank. Aescin was used as a standard and results were expressed as aescin equivalents (AEs) per gram of the dry weight of the bitter melon preparation used in the extraction (mg AE/g).

\section{Cell culture of pancreatic cells}

MiaPaCa2 primary pancreatic adenocarcinoma cells were maintained in Dulbecco's modified Eagle's medium contain- 


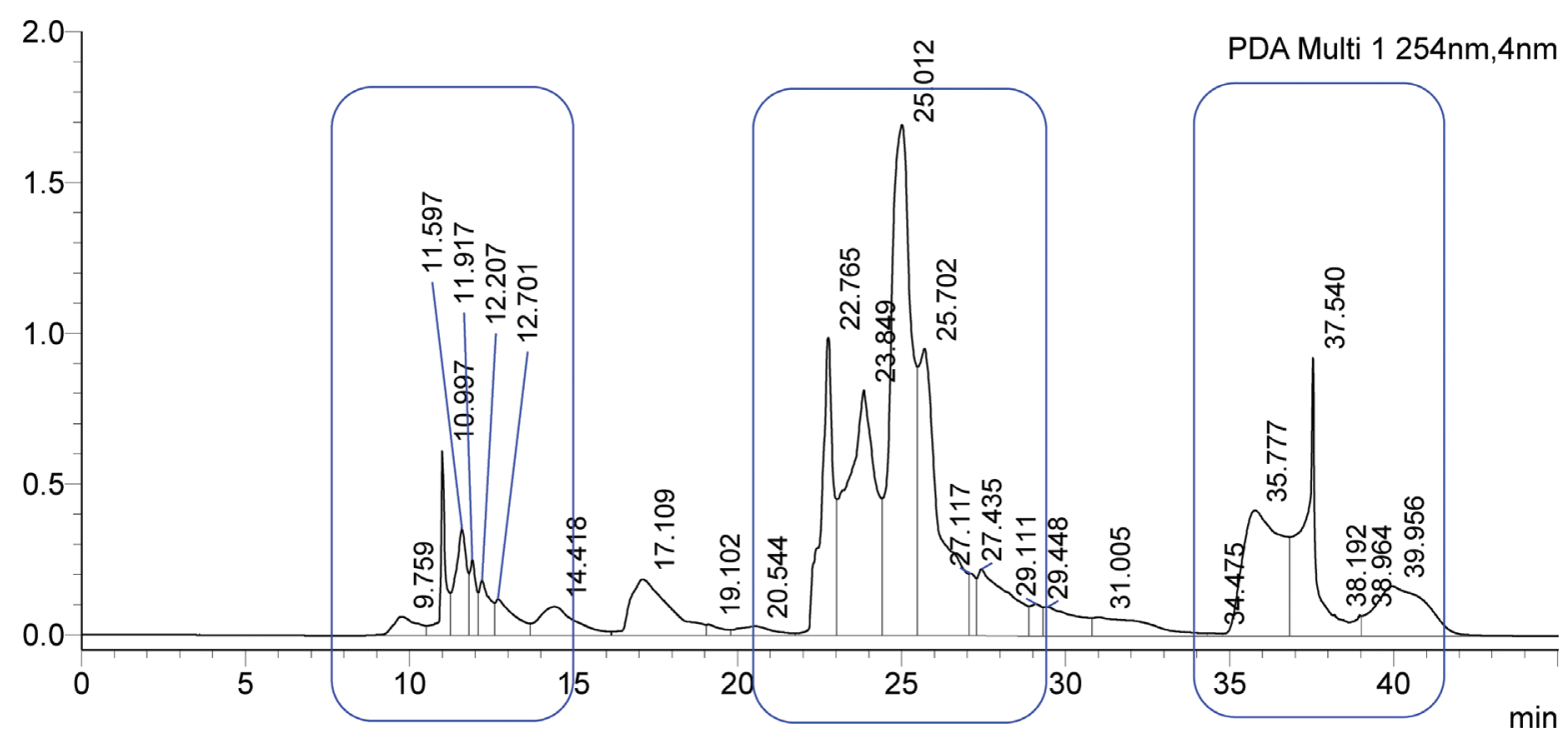

Fig. 1. HPLC chromatogram of CE and the three fractions. Absorbance was at $254 \mathrm{~nm}$ versus elution time (min). Abbreviations: CE, crude ethanol extract; HPLC, high-pressure liquid chromatography.

ing 10\% heat-inactivated fetal bovine serum (FBS), 2.5\% horse serum and $1 \%$ L-glutamine (L-Glu). CFPAC-1 PC cells, from a metastatic liver lesion, were kept in Iscove's modified Dulbecco's medium with $10 \%$ heat-inactivated FBS and 1\% L-Glu. BxPC3 primary pancreatic adenocarcinoma cells were kept in Roswell Park Memorial Institute medium containing 1\% L-Glu and 10\% heat-inactivated FBS. A comparatively normal human pancreatic ductal epithelial (HPDE) cell line was maintained in keratinocyte serum-free medium containing $5 \mathrm{ng} / \mathrm{mL}$ epidermal growth factor and $50 \mu \mathrm{g} / \mathrm{mL}$ bovine pituitary extract. All cell lines were obtained from the American Type Culture Collection (ATCC Laboratories, Manassas, VA, USA). Cells were split once $90 \%$ confluence was reached, using $0.25 \%$ trypsin to dissociate cells, and growth medium was changed every 2 days. Incubator conditions were maintained at a humidified $37{ }^{\circ} \mathrm{C}$ atmosphere containing $5 \% \mathrm{CO}_{2}$ in air. Growth media and supplements were obtained from ThermoFisher Scientific (formerly LifeTech), Australia.

\section{Determination of extract effect on cell viability}

To determine the effect of the two extracts, three fractions (F1, F2 $\&$ F3) and Cucurbitacin $\mathrm{B}(\mathrm{CuB})$ on cell viability, MiaPaCa2 $(3 \times$ $10^{3}$ cells per well $), \mathrm{BxPC} 3\left(7 \times 10^{3}\right.$ cells per well $), \operatorname{HPDE}\left(1 \times 10^{4}\right.$ cells per well $)$ and CFPAC- 1 cells $\left(7 \times 10^{3}\right.$ cells per well $)$ were cultured and seeded into 96 well plates. After seeding, the cells were incubated for $24 \mathrm{~h}$ prior to treating, to ensure adequate adhesion. A stock solution of the extracts and fractions was made to $400 \mathrm{mg} /$ $\mathrm{mL}$ in MilliQ and diluted in growth media, as required. Gemcitabine, dissolved in phosphate-buffered saline (PBS) to $1 \mathrm{mM}$ and stored at $-80.0{ }^{\circ} \mathrm{C}$, was thawed and diluted in fresh growth media on the day of use.

The cells were treated with doses of $\mathrm{SE}, \mathrm{CE}$ and Fractions $1-3$ ranging from $7-1,000 \mu \mathrm{g} / \mathrm{mL}$, and $\mathrm{CuB}$ doses ranging from $7-1,000 \mathrm{nM}$. Cells were incubated with treatment doses for 24, 48,72 or $96 \mathrm{~h}$. The treatments were compared to a positive control containing $50 \mathrm{nM}$ of gemcitabine in complete media and a negative (vehicle) control. Cell viability was determined using a colorimetric Cell Counting Kit-8 (CCK-8) assay (Dojindo Labora- tories, Inc, Rockville, MD, USA) and microplate reader at 450 nm (Benchmark Plus ${ }^{\mathrm{TM}}$; Bio-Rad, Hercules, CA, USA). A blank consisting of media and CCK-8 reagent was used and subtracted from all measurements prior to data analysis.

\section{Determination of apoptotic cell population}

To determine the apoptotic cell population after treatment with F3 and $\mathrm{CuB}$, a caspase 3/7 kit was used (Catalogue Number MCH100108; Merck Millipore, Australia). Firstly, cell samples were prepared by seeding MiaPaCa2 cells at a density of $3 \times 10^{5}$ cells per well, and HPDE cells at a density of $1 \times 10^{6}$ into a 12 -well plate, treating cells with 500 and $750 \mu \mathrm{g} / \mathrm{mL}$ of F3, and $25 \mathrm{nM}$ and $50 \mathrm{nM}$ of CuB for $24 \mathrm{~h}$. A positive control of gemcitabine at $50 \mathrm{nM}$ and negative (vehicle) control of MilliQ was used for F3. DMSO was used as the vehicle for $\mathrm{CuB}$. The cells were dissociated from the flask using $0.25 \%$ trypsin and resuspended in $50 \mu \mathrm{L} 1 \mathrm{X}$ assay buffer 'BA'. The cell suspension was mixed with $5 \mu \mathrm{L}$ of Muse Caspase-3/7 Reagent diluted 1:8 in PBS and incubated at $37{ }^{\circ} \mathrm{C}$ in $5 \% \mathrm{CO}_{2}$. After $30 \mathrm{~m}$ of incubation, $150 \mu \mathrm{L}$ of Muse ${ }^{\mathrm{TM}}$ Caspase 7-AAD Solution, consisting of $1.3 \%$ 7-AAD reagent in $1 \mathrm{X}$ Assay buffer BA, was added and incubated at room temperature in the dark for $5 \mathrm{~m}$. The sample was then loaded into the Muse ${ }^{\mathrm{TM}}$ Cell Analyzer and analyzed by Muse ${ }^{\mathrm{TM}}$ software (V1.4), as per the user's guide.

\section{Determination of cell cycle arrest}

To determine the effect of the bitter melon $\mathrm{F} 3$ and $\mathrm{CuB}$ on cell cycle progression, MiaPaCa2 and HPDE cells were treated with 500 $\mu \mathrm{g} / \mathrm{mL}$ and $750 \mu \mathrm{g} / \mathrm{mL}$ of $\mathrm{F} 3$, and $25 \mathrm{nM}$ and $50 \mathrm{nM} \mathrm{CuB}$ for $24 \mathrm{~h}$. After the $24 \mathrm{~h}$ period, the cells were fixed by resuspending $1 \times 10^{6}$ cells with ethanol $\left(70 \%\right.$; ice cold) and incubating at $-20^{\circ} \mathrm{C}$ for $3 \mathrm{~h}$. A $200 \mu \mathrm{L}$ aliquot of the fixed cell suspension was then centrifuged at $300 \mathrm{xg}$ for $5 \mathrm{~m}$, washed with PBS, pelleted and resuspended with $200 \mu \mathrm{L}$ of Muse ${ }^{\mathrm{TM}}$ Cell Cycle Stain (Muse ${ }^{\mathrm{TM}}$ Cell Cycle Kit, Catalogue Number MCH100106; Merck Millipore) before incubating 
Table 1. GI50 values of CE treatment $(\mu \mathrm{g} / \mathrm{mL})$ in MiaPaCa2, CFPAC-1, BxPC3 and HPDE cell lines calculated for 24, 48, 72 and $96 \mathrm{~h}$

\begin{tabular}{lllll}
\hline & \multicolumn{4}{c}{ CE GI50, $\boldsymbol{\mu g} / \mathrm{mL}$} \\
\hline CELL LINE & $24 \mathrm{~h}$ & $48 \mathrm{~h}$ & $72 \mathrm{~h}$ & $96 \mathrm{~h}$ \\
MiaPaCa2 & ND & $1,475.0$ & 711.6 & 821.8 \\
CFPAC-1 & ND & ND & ND & ND \\
BXPC3 & ND & ND & ND & ND \\
HPDE & ND & ND & ND & ND \\
\hline
\end{tabular}

Abbreviations: $\mathrm{CE}$, crude ethanol extract; GI50, minimum 50\% growth inhibitory concentration; HPDE, human pancreatic ductal epithelial; ND, not detected. Viability not reduced by more than $50 \%$.

in the dark at room temperature for $30 \mathrm{~m}$. The sample was then analyzed by a Muse ${ }^{\mathrm{TM}}$ Cell Analyzer.

\section{Statistical analysis}

All data was analyzed using GraphPad Prism (v7) software. Data are expressed as the arithmetic mean \pm standard deviation of a minimum three replicates. Statistical differences in viability between dose groups and negative control group were determined using multiple comparison one-way ANOVA, with $p<0.05$ deemed significant. 'Viability \%', a reflection of cell viability of treated compared to untreated cells, was calculated by dividing the mean absorbance of each treatment group (less the absorbance blank) by the mean absorbance of the negative control (less the absorbance blank) and multiplying by 100 . Dose response was analyzed using nonlinear regression of the $\log$ of the concentration with a defined bottom equal to 0.0 and constrained hillslope of -1.0 to determine the minimum $50 \%$ growth inhibitory concentration (GI50), a measure of drug potency. Statistical differences between treatment groups and negative controls of the cell cycle and apoptosis assays were calculated using multiple comparison two-way ANOVA, with $p<0.05$ deemed significant.

Results

\section{Assessment of bitter melon extracts on pancreatic cell viability}

\section{Total saponin content}

Total saponin content of the CE was $1.12 \mathrm{mg} \mathrm{AE} / \mathrm{g}$ dry weight and its n-butanol fraction was considerably higher in saponins, with $345.62 \mathrm{mg} \mathrm{AE} / \mathrm{g}$ dry weight.

\section{Effect of CE on pancreatic cell viability}

Pancreatic cell viability after a 24, 48, 72 and 96 h treatment with $\mathrm{CE}$ was assessed using a CCK-8 assay. The CE showed cytotoxic activity towards $\mathrm{MiaPaCa} 2$ cells dosed with the highest concentration $(1,000 \mu \mathrm{g} / \mathrm{mL})$ for longer time periods $(>48 \mathrm{~h})$. Similarly, CFPAC- 1 cells only reduced viability to $1,000 \mu \mathrm{g} / \mathrm{mL}$. MiaPaca2 and HPDE cells did not decrease in viability after the $24 \mathrm{~h}$ treatment with concentrations of CE between $0-1,000 \mu \mathrm{g} / \mathrm{mL}$. GI50 values were calculated for these treatments and were all $>500 \mu \mathrm{g} /$ $\mathrm{mL}$ (Table 1). MiaPaCa2 cells treated for $48 \mathrm{~h}$ with $1,000 \mu \mathrm{g} / \mathrm{mL}$
Table 2. GI50 values of SE treatment $(\mu \mathrm{g} / \mathrm{mL})$ in MiaPaCa2, CFPAC-1, BxPC3 and HPDE cell lines calculated for 24, 48, 72 and $96 \mathrm{~h}$

\begin{tabular}{lllll}
\hline \multicolumn{5}{c}{ SE GI50, $\mu \mathrm{g} / \mathrm{mL}$} \\
\hline CELL LINE & $24 \mathrm{~h}$ & $48 \mathrm{~h}$ & $72 \mathrm{~h}$ & $96 \mathrm{~h}$ \\
MiaPaCa2 & $1,669.0$ & 783.5 & 350.8 & 338.2 \\
CFPAC-1 & ND & ND & 599.7 & 776.8 \\
BXPC3 & ND & $1,010.0$ & 859.9 & 553.4 \\
HPDE & 88.1 & 87.4 & 72.1 & 164.0 \\
\hline
\end{tabular}

Abbreviations: GI50, minimum 50\% growth inhibitory concentration; HPDE, human pancreatic ductal epithelial; SE, saponin-enriched extract; ND, not detected. Viability not reduced by more than $50 \%$.

of CE decreased viability to a greater extent than the cells treated with gemcitabine (see Supplementary Fig. 1F). BxPC3 cells treated with the $\mathrm{CE}$ showed reduced viability after 48 and $96 \mathrm{~h}$ at doses above $125 \mu \mathrm{g} / \mathrm{mL}$ but no change was observed for the 24 or $72 \mathrm{~h}$ treatments. GI50 values for CE were not able to be calculated for the CFPAC-1 and BxPC3 cell lines (Table 1). The CE had poor cytotoxic potential overall but at its highest dose, affected only cancerous $\mathrm{MiaPaCa} 2$ and $\mathrm{CFPAC}-1$ cell lines.

\section{Effect of SE on pancreatic cell viability}

Pancreatic cell viability after 24, 48, 72 and 96 h treatment with SE was assessed using a CCK- 8 colorimetric assay. MiaPaCa2 and HPDE cells treated with the SE for 24, 48, 72 and $96 \mathrm{~h}$ exhibited decreasing cell viability with increasing concentrations $(>125 \mu \mathrm{g} /$ $\mathrm{mL}$ ) for all time points. The $96 \mathrm{~h}$ GI50 for MiaPaCa2 cells was $338.2 \mu \mathrm{g} / \mathrm{mL}$, approximately $80 \%$ less than the GI50 for the 24 h treatment of $1,669.0 \mu \mathrm{g} / \mathrm{mL}$ (Table 2). The GI50 value for the SE in HPDE cells was $88.1 \mu \mathrm{g} / \mathrm{mL}$ for $24 \mathrm{~h}$, which decreased to $72.05 \mu \mathrm{g} / \mathrm{mL}$ for $72 \mathrm{~h}$, but at $96 \mathrm{~h}$ increased again to $164.0 \mu \mathrm{g} / \mathrm{mL}$ (Table 2).

No decrease in viability of CFPAC-1 cells and BxPC3 treated with the SE for $24 \mathrm{~h}$ were observed. SE only reduced viability of CFPAC- 1 cells after $72 \mathrm{~h}$ from 1,000 $\mu \mathrm{g} / \mathrm{mL}$. After $96 \mathrm{~h}, \mathrm{CF}-$ PAC-1 cells demonstrated a dose-dependent reduction in viability, increasing the GI50 from $599.7 \mu \mathrm{g} / \mathrm{mL}$ to $776.8 \mu \mathrm{g} / \mathrm{mL}$ from the 72 to $96 \mathrm{~h}$ treatments. BxPC3 cells treated with the SE for $48-96 \mathrm{~h}$ observed a dose-dependent reduction in viability with GI50 values decreasing 2-fold, from $1,010.0 \mu \mathrm{g} / \mathrm{mL}$ at $48 \mathrm{~h}$ to $553.4 \mu \mathrm{g} / \mathrm{mL}$ at $96 \mathrm{~h}$ (Table 2). The SE showed minimal to slight cytotoxic activity overall; however, the lowest doses $(<100 \mu \mathrm{g} / \mathrm{mL})$ affected the HPDE cells within the first $24 \mathrm{~h}$, and low doses $(<500 \mu \mathrm{g} / \mathrm{mL})$ only showed a cytotoxic effect in MiaPaCa2 cells and only after $72 \mathrm{~h}$ (Table 2).

\section{Cytotoxicity of CE fractions on pancreatic cell lines in vitro}

The CE was semi-purified by HPLC into Fractions 1-3 (F1, F2 and F3) and their cytotoxicity was assessed on first HPDE and MiaPaCa2 cell viability using a $24 \mathrm{~h}$ CCK-8 assay. There was no reduction in $\mathrm{MiaPaCa} 2$ cell viability observed in response to $24 \mathrm{~h}$ treatment with F1 $(0-1,000 \mu \mathrm{g} / \mathrm{mL})$, while HPDE cell viability decreased following treatment with F1 (>125 $\mu \mathrm{g} / \mathrm{mL}$; Fig. 2A, E). F2 produced a dose-dependent reduction in viability of HPDE cells at $24 \mathrm{~h}$ with $1,000 \mu \mathrm{g} / \mathrm{mL}$, while MiaPaCa2 cells did not show any decrease in viability (Fig. 2B, F). F3 was the only fraction to de- 
A
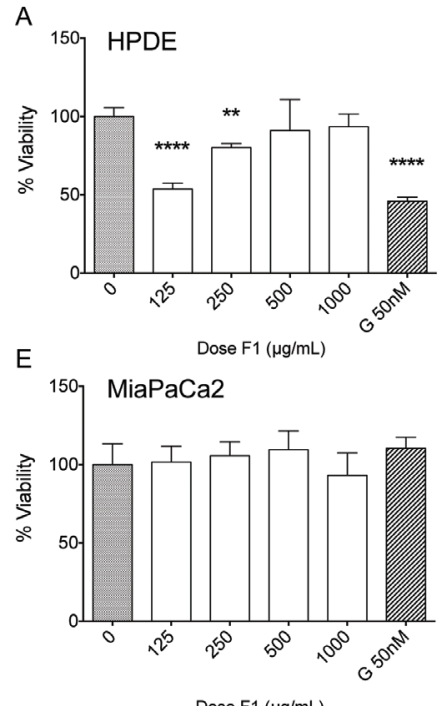

B

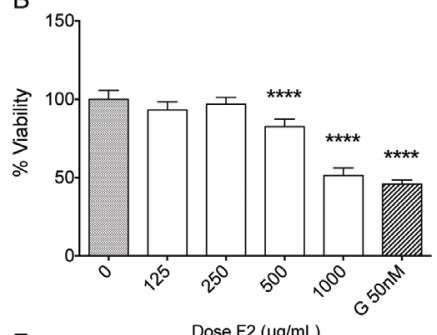

F

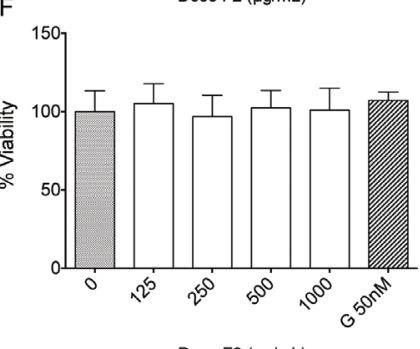

C

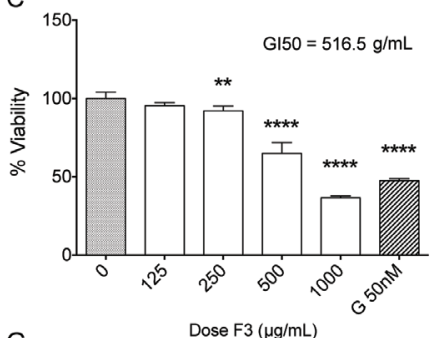

G

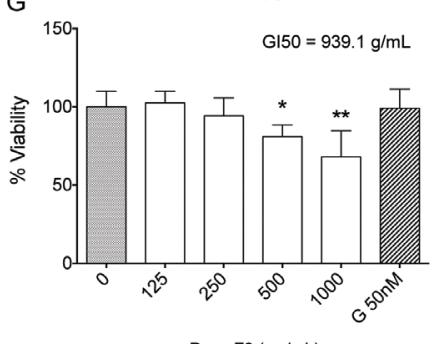

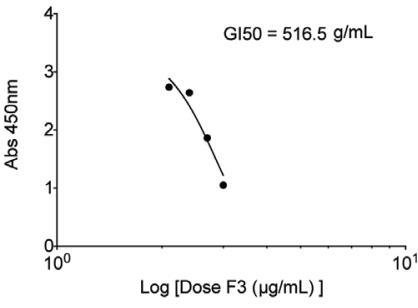

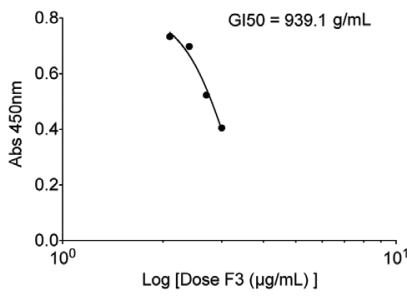

Fig. 2. Viability of HPDE and MiaPaCa2 cells treated for $24 \mathrm{~h}$ with Fractions 1-3 ranging from $0-1,000 \mu \mathrm{g} / \mathrm{mL}$ and gemcitabine $50 \mathrm{nM}$ (G $50 \mathrm{nM}$ ), as determined by CCK-8 colorimetric assay. HPDE cells treated for $24 \mathrm{~h}$ with A: Fraction 1, B: Fraction 2, C: Fraction 3, D: GI50 for Fraction 3 in HPDE cells at $516.5 \mu \mathrm{g} /$ $\mathrm{mL}$, MiaPaCa2 cells treated with E: Fraction 1, F: Fraction 2, G: Fraction 3, MiaPaCa2 cells; H: GI50 for Fraction 3 in MiaPaCa2 cells 939.1 ug/mL. Significance between treatment groups and the negative control calculated using one-way ANOVA represented over treatment columns by ${ }^{\prime * \prime}=p<0.05,{ }^{\prime *} * \prime=p<0.01$, $' * * * \prime=p<0.005,^{\prime * * * * \prime}=p<0.001$. Abbreviations: CCK-8, Cell Counting Kit-8; HPDE, human pancreatic ductal epithelial.

crease the MiaPaCa2 cell viability in 24 hours and produced GI50 values of $939.1 \mu \mathrm{g} / \mathrm{mL}$ and $516.5 \mu \mathrm{g} / \mathrm{mL}$ in MiaPaca2 and HPDE cells, respectively, and as such F3 was further investigated (Fig. $2 \mathrm{C}, \mathrm{D}, \mathrm{G}$, and $\mathrm{H})$.

F3 was assessed for its effect on cell viability for more than $24 \mathrm{~h}$ and in the additional two cancer cell lines. At 48 and $72 \mathrm{~h}$ F3 at high doses $(<500 \mu \mathrm{g} / \mathrm{mL})$ reduced viability of HPDE cells (see Supplementary Fig. 4). Doses above $250 \mu \mathrm{g} / \mathrm{mL}$ reduced Mia$\mathrm{PaCa} 2$ cell viability at $24 \mathrm{~h}$, while only doses greater than $500 \mu \mathrm{g} /$ $\mathrm{mL}$ showed an effect at $48 \mathrm{~h}$. Interestingly, no reduction in Mia$\mathrm{PaCa} 2$ viability at any dose was observed after $72 \mathrm{~h}$. The reduction of viable MiaPaCa2 cells in $48 \mathrm{~h}$ was not greater than $50 \%$ and, thus, no GI50 was able to be calculated (Table 3). A dose-dependent reduction in viability of CFPAC-1 and $\mathrm{BxPC} 3$ cells treated with $\mathrm{F} 3$ for $24 \mathrm{~h}$ was observed. This reduction in viability continued only for BxPC3 cells with the 48, 72 and $96 \mathrm{~h}$ treatments, and the GI50 value reduced from $1,883.0 \mu \mathrm{g} / \mathrm{mL}$ at $24 \mathrm{~h}$ to $547.8 \mu \mathrm{g} /$ $\mathrm{mL}$ at $96 \mathrm{~h}$ (Table 3). Of the three fractions made from CE, only F3 held cytotoxic potential towards cancer cells but none of the GI50 values were below $500 \mu \mathrm{g} / \mathrm{mL}$, even after $96 \mathrm{~h}$, indicating its cytotoxic action is not strong.

\section{Cytotoxicity of the commercially prepared triterpenoid $\mathrm{CuB}$}

The cytotoxicity of the commercially prepared triterpenoid $\mathrm{CuB}$ was assessed on the four pancreatic cell lines using CCK-8 viability assay. MiaPaCa2 PC cells treated with $\mathrm{CuB}(0-1,000 \mathrm{nM})$ showed a dose-dependent reduction in viability with increasing doses of $\mathrm{CuB}$. After $24 \mathrm{~h}$, cell viability reduced from concentrations above $15.81 \mathrm{nM}$ with no further reduction observed at concentrations higher than $62.50 \mathrm{nM}$. After $96 \mathrm{~h}$, reduction in cell viability was observed at doses of $31.25 \mathrm{nM}$ or higher (see Supplementary Fig. 5).

$\mathrm{HPDE}$ cells treated with $\mathrm{CuB}$ responded similarly to $\mathrm{MiaPaCa} 2$ cells, with the $72 \mathrm{~h}$ treatment producing the lowest GI50 of 15.30
$\mathrm{nM}$, at which there was close to $100 \%$ reduction in viability of HPDE cells treated with gemcitabine (Fig. 3C, D). CFPAC-1 cells had reduced viability after $72 \mathrm{~h}$ at a $\mathrm{CuB}$ dose of $62.50 \mathrm{nM}$. The GI50 of BxPC3 cells treated with $\mathrm{CuB}$ for $24 \mathrm{~h}$ was not able to be calculated, however, after $48 \mathrm{~h}$ the viability of $\mathrm{BxPC} 3$ cells started to decrease. The BxPC3 GI50 was $9.38 \mathrm{nM}$ after $48 \mathrm{~h}$ and 15.63 $\mathrm{nM}$ after $96 \mathrm{~h}$ (Table 4). All CuB GI50 values for all cell lines were less than $100 \mathrm{nM}$ after $96 \mathrm{~h}$, suggesting strong cytotoxic action of this triterpenoid.

\section{Effect of bitter melon extracts on pancreatic cell cycle arrest}

MiaPaCa2 and HPDE cells were treated with F3 at 500 and 750 $\mu \mathrm{g} / \mathrm{mL}$ for $48 \mathrm{~h}$ to determine if progression of the cells through the cell cycle could be stalled. HPDE cells treated with F3 for $48 \mathrm{~h}$ demonstrated an increased number of cells in the G1/0 phase, fewer cells in the $\mathrm{S}$ phase and significantly less cells in the $\mathrm{G} 2 / \mathrm{M}$ phase compared to the untreated cells (Fig. 4A). HPDE cells treated with gemcitabine also demonstrated a greater quantity of cells in the G1/0 phase than cells with no treatment, but to a greater extent

Table 3. GI50 values of $\mathrm{F} 3$ treatment $(\mu \mathrm{g} / \mathrm{mL})$ in MiaPaCa2, CFPAC-1, BXPC3 and HPDE cell lines calculated for 24, 48, 72 and $96 \mathrm{~h}$

\begin{tabular}{lllll}
\hline \multicolumn{5}{c}{ F3 GI50, $\mathrm{\mu g} / \mathrm{mL}$} \\
\hline CELL LINE & $24 \mathrm{~h}$ & $48 \mathrm{~h}$ & $72 \mathrm{~h}$ & $96 \mathrm{~h}$ \\
MiaPaCa2 & 939.1 & $\mathrm{ND}$ & $\mathrm{ND}$ & $\mathrm{NA}$ \\
CFPAC-1 & $1,860.0$ & $\mathrm{ND}$ & $\mathrm{ND}$ & $\mathrm{ND}$ \\
BxPC3 & $1,883.0$ & $1,168.0$ & 651.5 & 547.8 \\
HPDE & 516.5 & 942.6 & 857.1 & $\mathrm{NA}$ \\
\hline
\end{tabular}

Abbreviations: $\mathrm{F} 3$, fraction 3 ; GI50, minimum $50 \%$ growth inhibitory concentration HPDE, human pancreatic ductal epithelial; ND, not detected. Viability not reduced by more than 50\%; NA, not available. Assay not performed. 
A

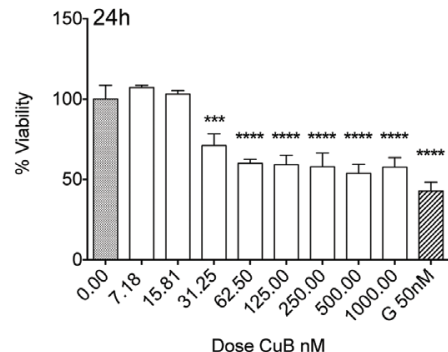

E

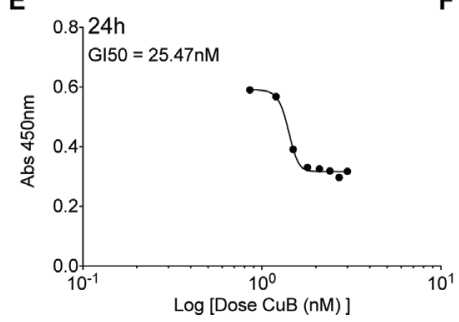

B
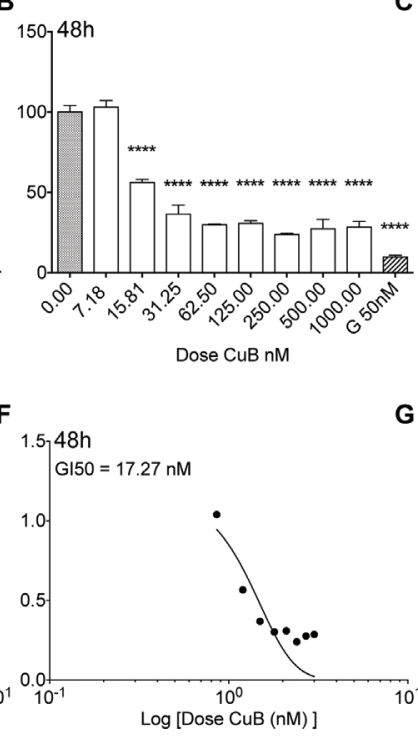

C
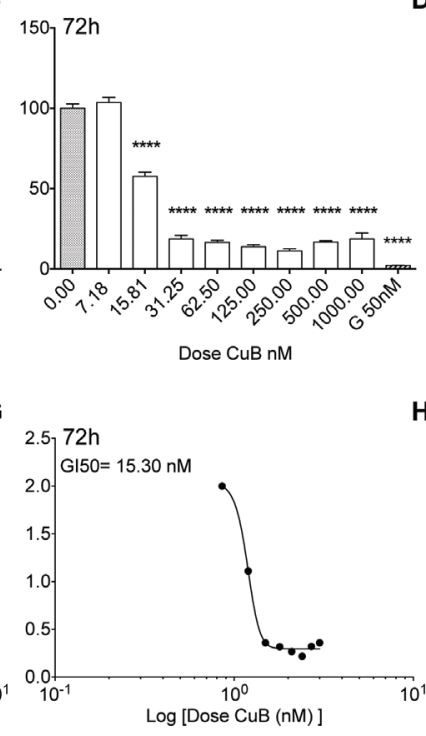

H
D

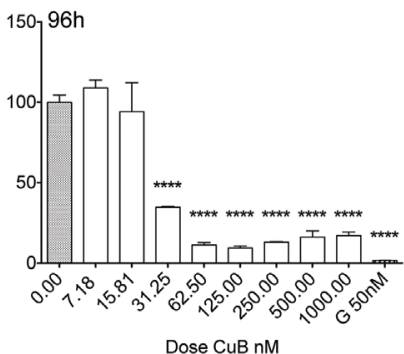

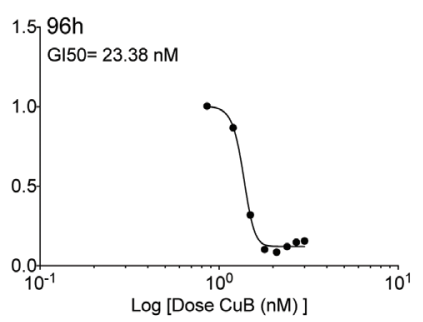

Fig. 3. Viability of HPDE cells treated with CuB ranging from $0-1,000 \mathrm{nM}$ and gemcitabine $50 \mathrm{nM}$ (G $50 \mathrm{nM}$ ), as determined by CCK-8 colorimetric assay. HPDE cells treated with CuB for A: 24 h, B: 48 h, C: 72 h, D: 96 h. GI50 values of HPDE cells are E: 25.47 nM for 24 h, F: 17.27 nM for 48 h, G: 15.30 nM for $72 \mathrm{~h}, \mathrm{H}: 23.38 \mathrm{nM}$ for $96 \mathrm{~h}$. Significance between treatment groups and the negative control calculated using one-way ANOVA represented over treatment columns by ${ }^{\prime * \prime}=p<0.05,^{\prime * * \prime}=p<0.01,{ }^{\prime * * * \prime}=p<0.005,{ }^{\prime} * * * * \prime=p<0.001$. Abbreviations: CCK-8, Cell Counting Kit-8; CuB, Cucurbitacin B; HPDE, human pancreatic ductal epithelial.

than seen with F3. The MiaPaCa2 cells treated with F3 had more cells in the G1/0 phase and less in the S phase for both treatment concentrations compared to untreated cells (Fig. 4B). This was similar to the gemcitabine-treated cells. HPDE cells treated with 25 and $50 \mathrm{nM} \mathrm{CuB}$ for $24 \mathrm{~h}$ revealed that treatment with $50 \mathrm{nM}$ significantly increased the population of cells in the G2/M phase compared to untreated cells (Fig. 4C). F3 appeared to induce G1/0 phase cell cycle arrest in both MiaPaCa2 and HPDE cells, while $\mathrm{CuB}$ appeared to induce $\mathrm{G} 2 / \mathrm{M}$ arrest.

\section{Effect of bitter melon extracts on apoptosis of pancreatic cells in vitro}

The caspase 3/7 assay was performed to determine if F3 could induce caspase 3/7-dependent apoptosis in the HPDE and Mia$\mathrm{PaCa} 2$ cells at $24 \mathrm{~h}$. Despite the appearance of apoptotic populations increasing in HPDE cells treated with 500 and $750 \mu \mathrm{g} / \mathrm{mL}$ of F3 (Fig. 5A), there were no significant differences between cells treated with F3 compared to the negative control. Similarly, there

Table 4. GI50 values of Cucurbitacin B treatment (nM) in MiaPaCa2, CFPAC-1, BxPC3 and HPDE cell lines calculated for 24, 48, 72 and $96 \mathrm{~h}$

\begin{tabular}{lllll}
\hline & \multicolumn{4}{c}{ CuB GI50, nM } \\
\hline CELL LINE & $24 \mathrm{~h}$ & $48 \mathrm{~h}$ & $72 \mathrm{~h}$ & $96 \mathrm{~h}$ \\
MiaPaCa2 & 14.76 & 39.22 & 35.21 & 66.69 \\
CFPAC-1 & ND & ND & 52.65 & 60.81 \\
BXPC3 & ND & 9.38 & 15.32 & 15.63 \\
HPDE & 25.47 & 17.27 & 15.30 & 23.38 \\
\hline
\end{tabular}

Abbreviations: GI50, minimum 50\% growth inhibitory concentration; HPDE, human pancreatic ductal epithelial; ND, not detected. Viability not reduced by more than $50 \%$. appeared to be increasing populations of dead cells, increasing in MiaPaCa2 cells with doses of F3 (Fig. 5B), yet these were statistically insignificant. As expected, the positive control gemcitabine revealed significant increases in apoptotic and dead populations in both cell lines (Fig. 5A, B). CuB at $50 \mathrm{nM}$ increased the total apoptotic and dead populations but only in HPDE cells (Fig. 5C, D). F3 did not appear to cause apoptosis in the MiaPaCa2 and HPDE cells, while $\mathrm{CuB}$ induced apoptosis at $50 \mathrm{nM}$ but only in HPDE cells.

\section{Discussion}

PC is a lethal disease. Natural sources, such as bitter melon, offer novel options for therapeutic development that may overcome the present challenges impeding current treatment efficacy. Previous studies have reported that the juice and extracts of bitter melon inhibit the growth of specific cancer cells by causing cell cycle arrest and apoptosis, and reducing the metastatic potential of this disease. Due to the anticancer potential of bitter melon, which contains high levels of saponin compounds, this study investigated the cytotoxic potential of a bitter melon ethanol extract and its saponin enriched $\mathrm{n}$-butanol fraction on pancreatic cells in vitro.

The crude bitter melon extract only reduced viability in Mia$\mathrm{PaCa} 2$ cells (at $1,000 \mu \mathrm{g} / \mathrm{mL} ;>48 \mathrm{~h}$ ) and did not appear to affect the HPDE cells. To understand if a selective cytotoxic action existed, it was explored further. Whole fruit aqueous extracts of a Chinese bitter melon have displayed preferential cytotoxicity towards breast cancer and leukemia cells, without effecting the viability of normal cells. ${ }^{29,30}$ Similarly, saponin-rich extracts selectively induced apoptosis in hepatoma cells, without causing the same effect in their normal counterparts. ${ }^{31}$ In this study, the SE did not discriminate in its cytotoxic activity and, in fact, was more potent to the HPDE cells. The lower doses $(125$ and $250 \mu \mathrm{g} / \mathrm{mL})$ required longer treatment times, of 72 or $96 \mathrm{~h}$, before any observed 
A

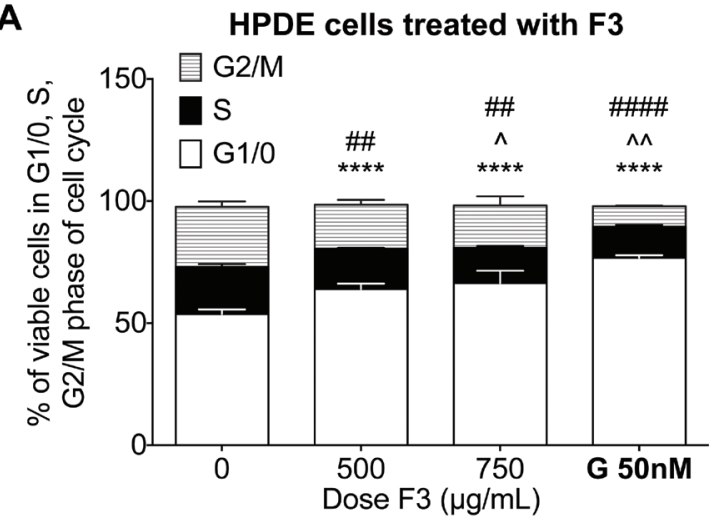

B

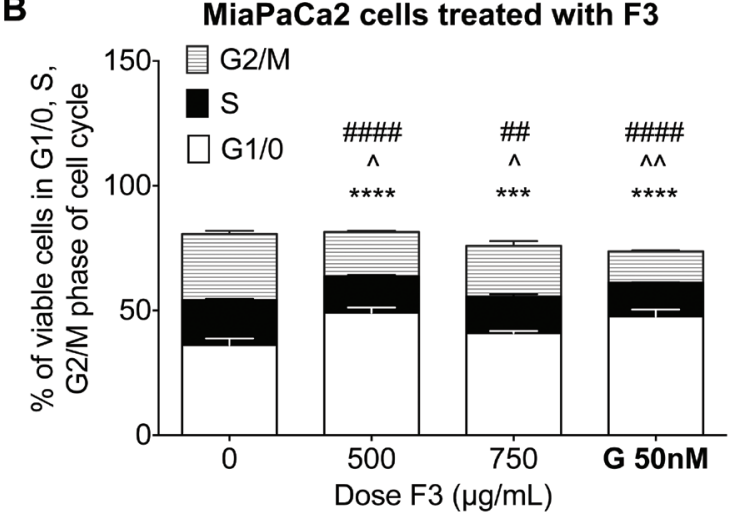

C

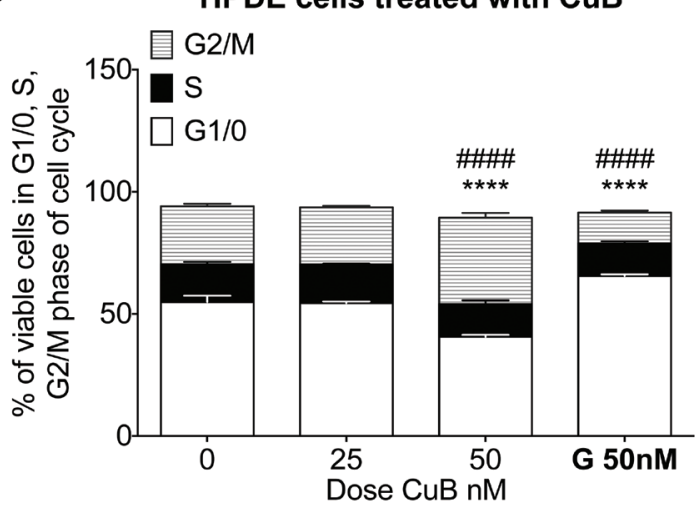

Fig. 4. Cell cycle analysis of HPDE and MiaPaCa2 Cells treated with F3 (0$750 \mu \mathrm{g} / \mathrm{mL})$ and CuB $(0-50 \mathrm{nM})$ for 48 -hours as determined using Muse $\mathrm{e}^{\mathrm{TM}}$ Cell Cycle Kit. A: HPDE cells treated with F3, B: MiaPaCa2 cells treated with F3, C: HPDE cells treated with CuB. Statistical differences between treatment groups and negative control determined by one-way ANOVA. $p<0.05$ represented by ' $*$ ', ' $\wedge$ ' and ' $\#$ ' for G1/0, S and G2/M phases, respectively. $p<0.01$ represented by '**', ' $\wedge \wedge^{\prime}$ ', '\#\#' for G1/0, $\mathrm{S}$ and G2/M phases, respectively. $p<0.005$ represented by '***', ' $\wedge \wedge \wedge$ ' and '\#\#\#' for the three cell

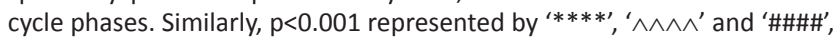
respectively. Abbreviations: CuB, Cucurbitacin B; F3, fraction 3; HPDE, human pancreatic ductal epithelial.

reduction in cancer cell viability, specifically for the CFPAC-1 and BxPC3 cells, which showed no response to SE in the first $24 \mathrm{~h}$. This may be due to differences between the mechanisms and kinetics of cell death, such as the cells' ability to absorb the compounds in a given time. ${ }^{32}$

Over time, the effect of the same concentration of SE appeared to reduce, with more viability of HPDE cells after $96 \mathrm{~h}$ than at 72 $\mathrm{h}$. This could indicate that the bioactive compound/s in the SE had been fully utilized by the HPDE cells in the $72 \mathrm{~h}$ timeframe, with remaining cells proliferating in the final $24 \mathrm{~h}$ to give the observed increase in viability at $96 \mathrm{~h}$. Despite this, it was clear that there was no specificity of action by the saponin extract. This might suggest that compounds other than saponins may confer this effect, that the responsible compound/s might have been excluded from the preparation of the extract via the butanol fractionation step, or that there may have been other reasons for only the $\mathrm{MiaPaCa} 2$ and CFPAC-1 cells being affected by the CE.

The crude extract was subjected to partial purification by HPLC in an attempt to elucidate the phytochemical profile of the bitter melon. The dose-dependent effect of F3 on BxPC3 cells was not observed in CFPAC-1 or MiaPaCa2 cells, indicating a sustained effect of F3 in the BxPC3 PC cells. This infers that the BxPC3 cells may be more sensitive to F3 than the other cell lines. The GI50 for both MiaPaCa2 and HPDE cells treated with F3 increased with time, and only reduced in $\mathrm{MiaPaCa} 2$ cell viability in response to F3 in the first $48 \mathrm{~h}$, leaving cells apparently unaffected at 72 and $96 \mathrm{~h}$. It is possible that re-administering the drug after the first $24 \mathrm{~h}$ may be necessary for MiaPaCa2 and CFPAC-1 cells.

After testing SE and the three fractions, it is clear that no selective cytotoxic action was present. There may have been synergism between compounds to cause the $\mathrm{CE}$ to only reduce $\mathrm{MiaPaCa} 2$ and CFPAC-1 cells that was lost when partially purifying to obtain the fractions. Synergistic effects of saponin compounds with therapeutic compounds have been reported to result in an increased cytotoxic capability. ${ }^{33}$ BMJ has also targeted multiple signaling pathways in a gemcitabine-resistant PC PanC cell line and increase their susceptibility to the effects of the drug. ${ }^{12}$

Gemcitabine is the standard treatment for PC; however, in the first $24 \mathrm{~h}, \mathrm{MiaPaCa} 2$ cells are not responsive to the gemcitabine treatment but were slightly responsive to F3, but only minimally. Even though there was a short-lived action of F3 in HPDE and Mi$\mathrm{aPaCa} 2$ cells in these instances, $\mathrm{F} 3$ may work to weaken the cells and may sensitize them to other agents. Further work is needed to elucidate and isolate any synergistic potential of the extract and its active components.

Genetic variation between the cell lines may account for their differences in response to $\mathrm{F} 3$. The MiaPaCa2 and $\mathrm{BxPC} 3$ cells are both sourced from primary pancreatic adenocarcinomas, however they have different genetic profiles. MiaPaCa2 cells have mutations with oncogene $K R A S$, and tumor suppressor genes $C D K N 2 A$ and TP53, while BxPC3 cells have a wild-type $K R A S$ and also possess mutations in $C D K N 2 A$ and TP53 but have further mutations in SMAD4 and MAP2K4. ${ }^{34}$ CFPAC- 1 cells, by contrast, are cells derived from a metastatic site in the liver and have mutations in KRAS, SMAD4 and TP53. ${ }^{34}$ Further work is necessary to explore if inducing specific mutations; for example, KRAS in $\mathrm{BxPC} 3$ cells, gives these cells increased resistance to the effect of $\mathrm{F} 3$, as seen in the response to this fraction by $K R A S$-mutated MiaPaCa2 and CFPAC-1 cells. The synergistic capabilities of purified bitter melon agents could also then be explored in combination with gene knockouts or forced expressions to understand the relationship between genetic profile, drug interactions and drug responsiveness.

To understand how F3 reduced cell viability, caspase 3/7 apoptosis and cell cycle assays were performed. Apoptosis is a transient cellular process that involves numerous intermediate cellular signals to initiate the self-destruction of the cell. Caspase levels are likely to change with time as cells undergo necrosis, which is secondary to in vitro apoptosis. ${ }^{32}$ In MiaPaCa2 cells treated with F3, there were slight increases in the population of dead cells compared to 
A

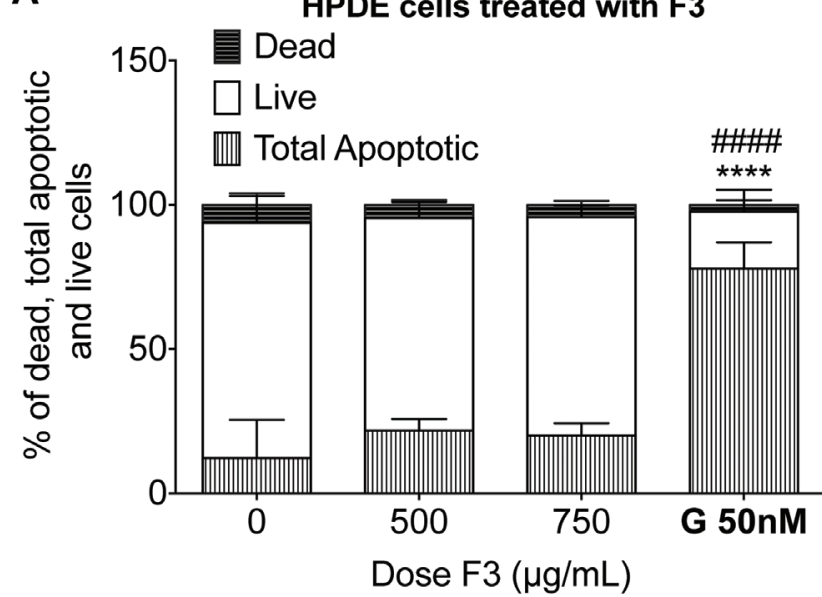

C

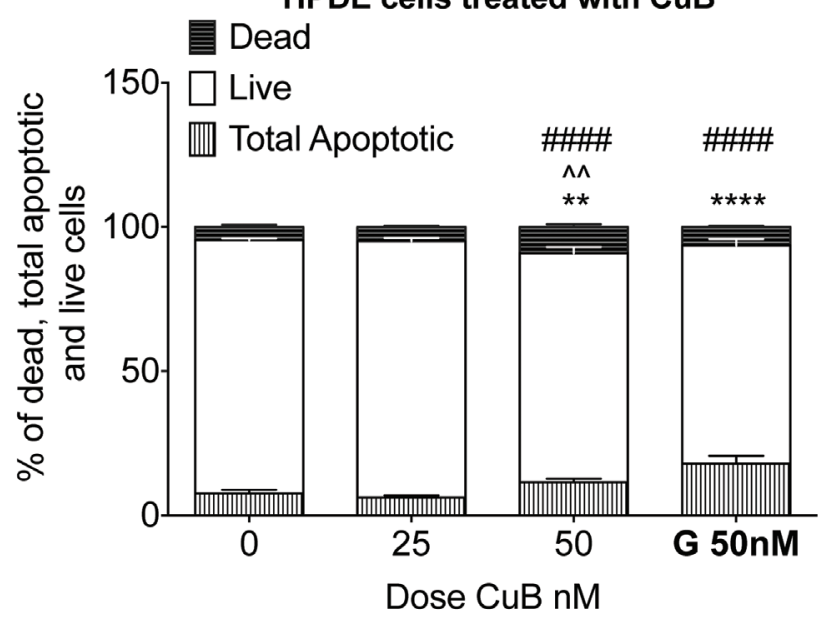

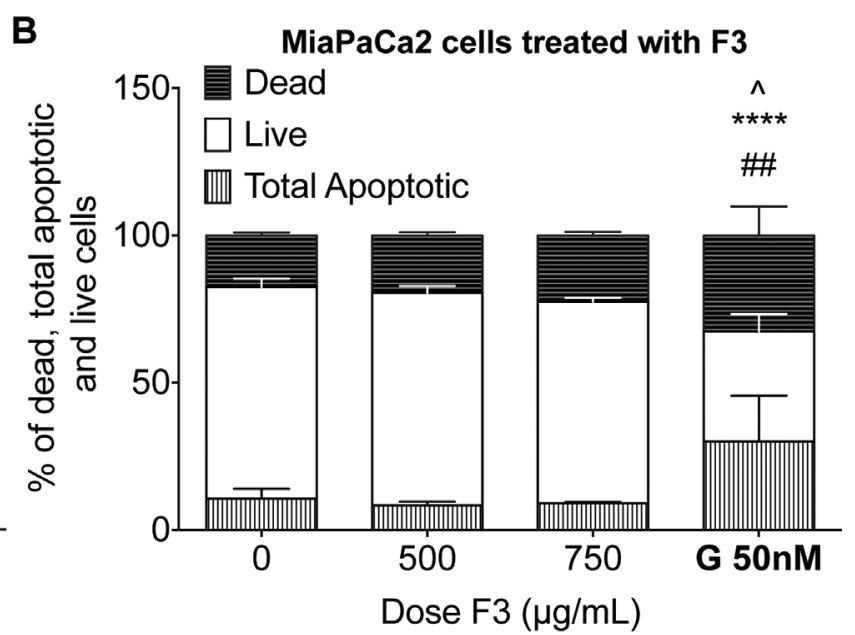

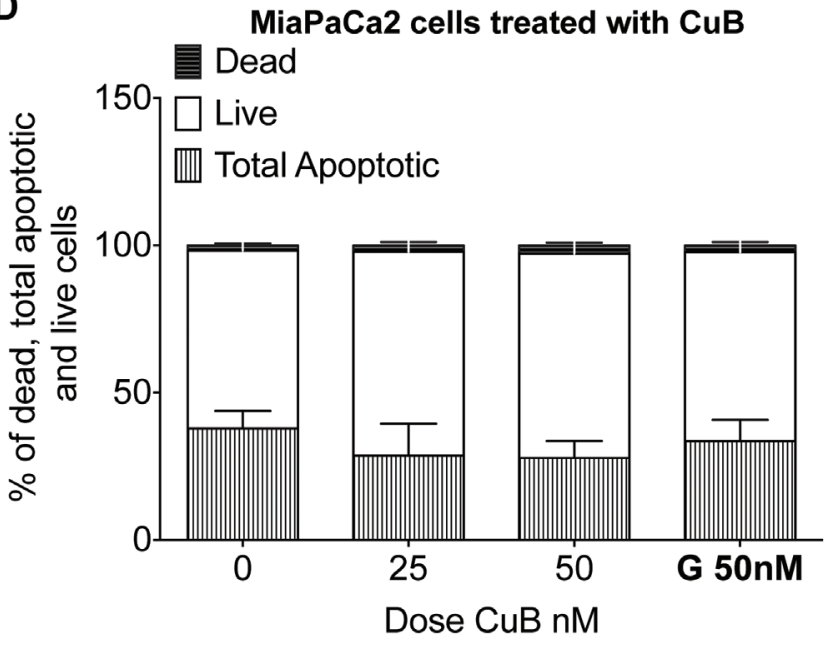

Fig. 5. Dead, live and total apoptotic HPDE and MiaPaCa2 cells after 24-hour treatment with F3 (0-750 $\mu \mathrm{g} / \mathrm{mL})$ and CuB (0-50 $\mathrm{nM})$ as determined using Muse $^{\mathrm{TM}}$ Caspase 3/7 kit. A: HPDE cells treated with F3, B: MiaPaCa2 cells treated with F3, C: HPDE cells treated with CuB, D: MiaPaCa2 cells treated with CuB. Statistical differences between treatment groups and negative control determined by one-way ANOVA. P<0.05 represented by '*', ' $\wedge$ ' and '\#' for G1/0, $\mathrm{S}$ and G2/M phases, respectively. $\mathrm{P}<0.01$ represented by '**', ' $\wedge \wedge^{\prime}$, '\#\#' for $\mathrm{G} 1 / 0, \mathrm{~S}$ and $\mathrm{G} 2 / \mathrm{M}$ phases, respectively. Similarly, $\mathrm{P}<0.001$ represented by '****', ' $\wedge \wedge \wedge$ ' and '\#\#\#\#', respectively. Abbreviations: CuB, Cucurbitacin B; F3, fraction 3; HPDE, human pancreatic ductal epithelial.

the negative control, though statistically insignificant. HPDE cells treated with the same doses had slight increases in total apoptotic populations, but again were not found to be significant. As such, further experiments with adjustments in treatment times will need to be explored to delineate the effects of bitter melon extracts on apoptosis of pancreatic cells. BMJ has been shown to increase caspase 7 and caspase 3 activity at $48 \mathrm{~h}$ in MCF-7 and MDA-MB-231 breast cancer cells. ${ }^{35}$ Indeed, further purification and concentration of purified components may increase their cytotoxic potential.

Following a $48 \mathrm{~h}$ treatment of both HPDE and MiaPaCa2 cells with F3, an increased number of cells in the G1/0 phase was observed, indicating that cell cycle arrest in the G1/0 phase may be induced by the bitter melon fraction. Considering that the cells do not continue to decrease in viability at the $72 \mathrm{~h}$ treatment, it is unlikely that cell cycle arrest is sustained. Cycle arrest can occur if the cell's internal checkpoints are not passed. ${ }^{36}$ The fate of the cell after mitotic cell cycle arrest may either be cell death, if sufficient signals are given to the cell to undergo apoptosis, such as with caspase signaling, or the cell may have adapted and will then go on to continue proliferating, as seen in cases of drug resistance. $^{37}$

The longer the cell remains in cell cycle arrest, whereby mitosis occurs until the cell breaks down the agent responsible for causing the arrest (cyclin B1), the less likely it is to survive. ${ }^{38}$ This potentially explains why the cells continue to proliferate after $72 \mathrm{~h}$ of treatment. Despite indications that cell cycle arrest may be occurring in these cells with treatment of F3, there was no confirmation of apoptosis, which could explain why the cells continue to proliferate. The accumulation of cells in the G1/0 phase was unexpected, as BMJ has been shown to increase populations in the G2/M phase although G1/0 arrest has also been induced by bitter melon, but in a bitter melon leaf ethanol extract. ${ }^{16,35,39}$

The cytotoxic potential of $\mathrm{CuB}$, a commercially prepared triterpenoid was also investigated. $\mathrm{CuB}$ elicited a strong dose response in BxPC3 PC cells, comparable to the gold standard chemotherapeutic agent gemcitabine. This was also confirmed in MiaPaCa2 PC cells, while interestingly 'preserving' HPDE cell viability to a greater extent than gemcitabine. $\mathrm{CuB}$ at $200 \mathrm{nM}$ has previously been found to induce apoptosis in a time-dependent manner in MiaPaCa2, Panc-1 and PL45 PC cells. ${ }^{40}$ However, in this study, 
$\mathrm{CuB}$ was tested at $50 \mathrm{nM}$ and induced caspase 3/7 apoptosis in the HPDE cells but not in the MiaPaCa2 cells. Cell cycle arrest in the $\mathrm{G} 2 / \mathrm{M}$ phase by $50 \mathrm{nM} \mathrm{CuB}$ was also observed in the HPDE cells. G2/M phase arrest was previously observed at $200 \mathrm{nM}$ in PC $\mathrm{MiaPaCa} 2$ and Panc- 1 cells. ${ }^{40}$ Despite $\mathrm{CuB}$ appearing to 'preserve' HPDE to a greater extent than gemcitabine in these studies, $\mathrm{CuB}$ clearly has a more potent effect to these normal pancreatic cells than to the cancerous cell lines.

\section{Future research directions}

While the cytotoxicity of the extracts was not strong, there is much more work that can be done, such as further purification of the extracts, which may increase their cytotoxic potential. Isolation and concentration of components that make up F3 may unveil an alternate bioactive agent, perhaps a cucurbitane triterpenoid or saponin, with the potential to induce significant cytotoxicity in PC cells. The synergistic capabilities of purified bitter melon agents could also then be explored in combination with gene knockouts or forced expressions to understand the relationship between genetic profile, drug interactions and drug responsiveness. Similarly, changes to protein levels and/or gene expression in the cells, such as in cyclin, caspase or Bak/Bax, to confirm the mechanisms of action are warranted. Further work is also necessary to explore if inducing specific mutations, e.g., KRAS in $\mathrm{BxPC} 3$ cells, gives these cells increased resistance to the effect of F3, as seen in the response to this fraction by $K R A S$-mutated $\mathrm{MiaPaCa} 2$ and $\mathrm{CF}$ PAC-1 cells.

\section{Conclusions}

Overall, both crude and saponin-enriched fractions were not effective at eliciting a cytotoxic response towards PC cells in vitro. Semi-purification of the crude extract, which displayed potential for selectively reducing viability of cancerous cells without the same effect to a comparatively normal pancreatic cell line HPDE, provided three fractions for further assessment. Of the three fractions, only $\mathrm{F} 3$ reduced the viability of $\mathrm{MiaPaCa} 2 \mathrm{PC}$ cells, and no further selective action was observed. The cytotoxic action of F3 was short-lived, with cells decreasing viability initially, and then increasing viability again with time. Investigations into the mechanism of action of F3 indicated that it potentially causes G1/0 cell cycle arrest, without appearing to induce apoptosis. In contrast, treatment with $\mathrm{CuB}$ suggests that a $\mathrm{G} 2 / \mathrm{M}$ cell cycle arrest occurred, as well as caspase 3/7-dependent apoptosis. Further research may assist in investigating these agents and why they have minimal effect in the treatment for PC while other bitter melon preparations have positive outcomes.

\section{Acknowledgments}

The authors would like to acknowledge the University of Newcastle and the Pancreatic Cancer Research Group for supporting this project.

\section{Conflict of interest}

The authors have no conflict of interests related to this publication.
Author contributions

Experimental conduct (RR), minor editing and supervisory role $(\mathrm{QV})$, main editor of manuscript and main supervisor (CS).

\section{Supporting information}

Supplementary material for this article is available at https://doi. org/10.14218/ERHM.2017.00032.

Supplementary Figure 1. Viability of HPDE and MiaPaCa2 cells treated with $\mathrm{CE}$ ranging from $0-1,000 \mu \mathrm{g} / \mathrm{mL}$ and Gemcitabine 50 $\mathrm{nM}$ determined by CCK 8 colourimetric assay. HPDE cells treated with $C E$ for $A: 24$ hours, $B: 48$ hours, $C: 72$ hours, D: 96 hours; MiaPaCa2 cells treated with CE for E: 24 hours F: 48 hours (GI50 1,475 $\mu \mathrm{g} / \mathrm{mL}$ ), G: 72 hours (GI50 $711.6 \mu \mathrm{g} / \mathrm{mL}$ ), H: 96 hours (GI50 $821.8 \mu \mathrm{g} / \mathrm{mL})$. Significance between treatment groups and the negative control calculated using one-way ANOVA represented over treatment columns by '*' $=p<0.05$, '**' $=p<0.01$, ' $* * *$ ' $=$ $p<0.005,{ }^{\prime} * * * *$ ' $=p<0.001$.

Supplementary Figure 2. Viability of MiaPaCa2 cells treated with Saponin fraction (SE) ranging from $0-2,000 \mu \mathrm{g} / \mathrm{mL}$ and Gemcitabine $50 \mathrm{nM}$ determined by CCK 8 colourimetric assay. $\mathrm{MiaPaCa} 2$ cells treated SE for A: 24 hours, B: 48 hours, C: 72 hours, D: 96 hours. GI50 values of MiaPaCa2 cells are E: 1,669.0 $\mu \mathrm{g} / \mathrm{mL}$ for 24 hours F: $783.5 \mu \mathrm{g} / \mathrm{mL}$ for 48 hours $G$ : $350.8 \mu \mathrm{g} / \mathrm{mL}$ for 72 hours and $H: 338.2 \mu \mathrm{g} / \mathrm{mL}$ for 96 hours. Significance between treatment groups and the negative control calculated using one-way ANOVA represented over treatment columns by '*' $=p<0.05$, ' $* *$ ' $=p<$

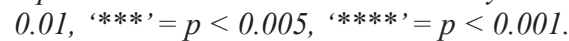

Supplementary Figure 3. Viability of HPDE cells treated with SE ranging from $0-1,000 \mu \mathrm{g} / \mathrm{mL}$ and Gemcitabine $50 \mathrm{nM}$ determined by CCK8 colourimetric assay. HPDE cells treated with SE for A: 24 hours, B: 48 hours, C: 72 hours, D: 96 hours. GI50 values of $S E$ cells E: $88.1 \mu \mathrm{g} / \mathrm{mL}$ for 24 hours $F: 87.35 \mu \mathrm{g} / \mathrm{mL}$ for 48 hours $G$ : $72.05 \mu \mathrm{g} / \mathrm{mL}$ for 72 hours and $\mathrm{H}: 164.00 \mu \mathrm{g} / \mathrm{mL}$ for 96 hours. Significance between treatment groups and the negative control calculated using one-way ANOVA represented over treatment columns by '*'

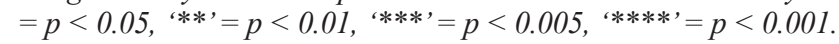

Supplementary Figure 4. Viability of HPDE and MiaPaCa2 cells treated with Fraction 3 (F3) ranging from $0-1,000 \mu \mathrm{g} / \mathrm{mL}$ and Gemcitabine $50 \mathrm{nM}$ as determined by CCK 8 colourimetric assay. HPDE cells treated with F3 for A: 24 hours (GI50 $516.5 \mu \mathrm{g} / \mathrm{mL})$, $B$ : 48 hours (GI50 942.6 $\mu \mathrm{g} / \mathrm{mL}$ ), C: 72 hours (GI50 857.1 $\mu \mathrm{g}$ ) mL), MiaPaCa2 cells treated with F3 for D: 24 hours (GI50 939.1 $\mu \mathrm{g} / \mathrm{mL}$ ) E: 48 hours, F: 72 hours. Significance between treatment groups and the negative control calculated using one-way ANOVA represented over treatment columns by '*' $=p<0.05$, '**' $^{*}=p<$ $0.01,{ }^{\prime} * * *$ ' $=p<0.005$, '****' $^{*} p<0.001$.

Supplementary Figure 5. Viability of MiaPaCa2 cells treated with Cucurbitacin $\mathrm{B}(\mathrm{CuB})$ ranging from $0-1,000 \mathrm{nM}$ and Gemcitabine $50 \mathrm{nM}$ as determined by CCK8 colourimetric assay. $\mathrm{MiaPaCa} 2$ cells treated with $C u B$ for A: 24 hours, B: 48 hours, $C: 72$ hours, D: 96 hours. GI50 values of MiaPaCa2 cells E: 14.76 nM for 24 hours F: 39.22 nM for 48 hours G: $35.21 \mathrm{nM}$ for 72 hours and $H$ : 66.69 nM for 96 hours. Significance between treatment groups and the negative control calculated using one-way ANOVA represented over treatment columns by '*' $=p<0.05$, '**' $=p<0.01$, ' $* * *$ ' $=$ 
Explor Res Hypothesis Med

$p<0.005$, '****' $=p<0.001$.

\section{References}

[1] Kleeff J, Korc M, Apte M, Vecchia CL, Johnson CD, Biankin AV, et al. Pancreatic cancer. Nat Rev Dis Primers 2016;2:16022. doi:10.1038/ nrdp.2016.22.

[2] Waddell N, Pajic M, Patch AM, Chang DK, Kassahn KS, Bailey P, et al. Whole genomes redefine the mutational landscape of pancreatic cancer. Nature 2015;518(7540):495-501. doi:10.1038/nature14169.

[3] Rossi ML, Rehman AA, Gondi CS. Therapeutic options for the management of pancreatic cancer. World J Gastroenterol 2014;20(32):11142-11159. doi:10.3748/wjg.v20.i32.11142.

[4] Vickers MM, Powell ED, Asmis TR, Jonker DJ, Hilton JF, O'Callaghan $\mathrm{CJ}$, et al. Comorbidity, age and overall survival in patients with advanced pancreatic cancer - results from NCIC CTG PA.3: a phase III trial of gemcitabine plus erlotinib or placebo. Eur J Cancer 2012;48(10):1434-1442. doi:10.1016/j.ejca.2011.10.035.

[5] Moore MJ, Parulekar W, Ding PK. In Reply. J Clin Oncol 2007:25(27):4321-4322. doi:10.1200/JCO.2007.13.1441.

[6] Moore MJ, Goldstein D, Hamm J, Figer A, Hecht JR, Gallinger S, et al. Erlotinib plus gemcitabine compared with gemcitabine alone in patients with advanced pancreatic cancer: a phase III trial of the $\mathrm{Na}$ tional Cancer Institute of Canada Clinical Trials Group. J Clin Oncol 2007:25(15):1960-1966. doi:10.1200/JCO.2006.07.9525.

[7] Nussbaumer S, Bonnabry P, Veuthey JL, Fleury-Souverain S. Analysis of anticancer drugs: a review. Talanta 2011;85(5):2265-2289. doi:10.1016/j.talanta.2011.08.034.

[8] Long J, Zhang Y, Yu X, Yang J, LeBrun DG, Chen C, et al. Overcoming drug resistance in pancreatic cancer. Expert Opin Ther Targets 2011;15(7):817-828. doi:10.1517/14728222.2011.566216.

[9] Zhan HX, Xu JW, Wu D, Zhang TP, Hu SY. Pancreatic cancer stem cells: New insight into a stubborn disease. Cancer Lett 2015;357(2):429437. doi:10.1016/j.canlet.2014.12.004.

[10] Hamada S, Masamune A, Shimosegawa T. Alteration of pancreatic cancer cell functions by tumor-stromal cell interaction. Front Physiol 2013;4:318. doi:10.3389/fphys.2013.00318.

[11] Li L, Leung PS. Use of herbal medicines and natural products: an alternative approach to overcoming the apoptotic resistance of pancreatic cancer. Int J Biochem Cell Biol 2014;53:224-236. doi:10.1016/j. biocel.2014.05.021.

[12] Somasagara RR, Deep G, Shrotriya S, Patel M, Agarwal C, Agarwal R. Bitter melon juice targets molecular mechanisms underlying gemcitabine resistance in pancreatic cancer cells. Int J Oncol 2015;46(4):1849-1857. doi:10.3892/ijo.2015.2885.

[13] Kaur M, Deep G, Jain AK, Raina K, Agarwal C, Wempe MF, et al. Bitter melon juice activates cellular energy sensor AMP-activated protein kinase causing apoptotic death of human pancreatic carcinoma cells. Carcinogenesis 2013;34(7):1585-1592. doi:10.1093/carcin/bgt081.

[14] Nagasawa H, Watanabe K, Inatomi H. Effects of bitter melon (Momordica charantia I.) or ginger rhizome (Zingiber offifinale rosc) on spontaneous mammary tumorigenesis in SHN mice. Am J Chin Med 2002:30(2-3):195-205. doi:10.1142/S0192415X02000302.

[15] Claflin AJ, Vesely DL, Hudson JL, Bagwell CB, Lehotay DC, Lo TM, et al. Inhibition of growth and guanylate cyclase activity of an undifferentiated prostate adenocarcinoma by an extract of the balsam pear (Momordica charantia abbreviata). Proc Natl Acad Sci U S A 1978;75(2):989-993.

[16] Pitchakarn P, Suzuki S, Ogawa K, Pompimon W, Takahashi S, Asamoto $\mathrm{M}$, et al. Kuguacin J, a triterpenoid from Momordica charantia leaf, modulates the progression of androgen-independent human prostate cancer cell line, PC3. Food Chem Toxicol 2012;50(3-4):840-847. doi:10.1016/j.fct.2012.01.009.

[17] Nerurkar P, Ray RB. Bitter melon: antagonist to cancer. Pharm Res 2010;27(6):1049-1053. doi:10.1007/s11095-010-0057-2.

[18] Murakami T, Emoto A, Matsuda H, Yoshikawa M. Medicinal Foodstuffs. XXI. Structures of New Cucurbitane-Type Triterpene Glycosides, Goyaglycosides-a, -b, -c, -d, -e, -f, - $\mathrm{g}$, and $-\mathrm{h}$, and New Oleanane-Type Triterpene Saponins, Goyasaponins I, II, and III, from the
Fresh Fruit of Japanese Momordica charantia L. Chem Pharm Bull (Tokyo) 2001;49(1):54-63.

[19] Choi S, Kim TW, Singh SV. Ginsenoside Rh2-mediated G1 phase cell cycle arrest in human breast cancer cells is caused by p15 Ink4B and p27 Kip1-dependent inhibition of cyclin-dependent kinases. Pharm Res 2009;26(10):2280-2288. doi:10.1007/s11095-009-9944-9.

[20] Wang CZ, Du GJ, Zhang Z, Wen XD, Calway T, Zhen Z, et al. Ginsenoside compound $\mathrm{K}$, not $\mathrm{Rb} 1$, possesses potential chemopreventive activities in human colorectal cancer. Int J Oncol 2012;40(6):19701976. doi:10.3892/ijo.2012.1399.

[21] Galanty A, Michalik M, Sedek L, Podolak I. The influence of LTS-4, a saponoside from Lysimachia thyrsiflora L., on human skin fibroblasts and human melanoma cells. Cell Mol Biol Lett 2008;13(4):585-598. doi:10.2478/s11658-008-0013-x.

[22] Gnoula C, Mégalizzi V, De Nève N, Sauvage S, Ribaucour F, Guissou P, et al. Balanitin-6 and -7: Diosgenyl saponins isolated from Balanites aegyptiaca Del. display significant anti-tumor activity in vitro and in vivo. Int J Oncol 2008;32(1):5-15. doi:10.3892/ijo.32.1.5.

[23] Ma R, Song G, You W, Yu L, Su W, Liao M, et al. Anti-microtubule activity of tubeimoside I and its colchicine binding site of tubulin. Cancer Chemother Pharmacol 2008;62(4):559-568. doi:10.1007/s00280007-0635-0.

[24] Einbond LS, Wen-Cai Y, He K, Wu HA, Cruz E, Roller M, et al. Growth inhibitory activity of extracts and compounds from Cimicifuga species on human breast cancer cells. Phytomedicine 2008;15(6-7):504511.

[25] Li M, Wei SY, Xu B, Guo W, Liu DL, Cui JR, et al. Pro-apoptotic and microtubule-disassembly effects of ardisiacrispin $(A+B)$, triterpenoid saponins from Ardisia crenata on human hepatoma Bel-7402 cells. J Asian Nat Prod Res 2008;10(7-8):739-746. doi:10.1080/10286020802016198.

[26] Kim YJ, Kwon HC, Ko H, Park JH, Kim HY, Yoo JH, et al. Anti-tumor Activity of the Ginsenoside Rk1 in Human Hepatocellular Carcinoma Cells through Inhibition of Telomerase Activity and Induction of Apoptosis. Biol Pharm Bull 2008;31(5):826-830. doi:10.1248/bpb.31.826.

[27] Srinivasan S, Koduru S, Kumar R, Venguswamy G, Kyprianou N, Damodaran C. Diosgenin targets Akt-mediated prosurvival signaling in human breast cancer cells. Int J Cancer 2009;125(4):961-967. doi:10.1002/ijc.24419.

[28] Tan SP, Vuong QV, Stathopoulos CE, Parks SE, Roach PD. Optimized aqueous extraction of saponins from bitter melon for production of a saponin-enriched bitter melon powder. J Food Sci 2014;79(7):E1372E1381. doi:10.1111/1750-3841.12514.

[29] Takemoto DJ, Dunford C, McMurray MM. The cytotoxic and cytostatic effects of the bitter melon (Momordica charantia) on human lymphocytes. Toxicon 1982;20(3):593-599. doi:10.1016/0041-0101 (82)90053-8.

[30] Takemoto DJ, Dunford C, Vaughn D, Kramer KJ, Smith A, Powell RG. Guanylate cyclase activity in human leukemic and normal lymphocytes. Enzyme inhibition and cytotoxicity of plant extracts. Enzyme 1982;27(3):179-188. doi:10.1159/000459047.

[31] Zhang W, Luo JG, Zhang C, Kong LY. Different apoptotic effects of triterpenoid saponin-rich Gypsophila oldhamiana root extract on human hepatoma SMMC-7721 and normal human hepatic L02 cells. Biol Pharm Bull 2013;36(7):1080-1087. doi:10.1248/bpb.b12-01069.

[32] Riss TL, Moravec RA. Use of multiple assay endpoints to investigate the effects of incubation time, dose of toxin, and plating density in cell-based cytotoxicity assays. Assay Drug Dev Technol 2004;Feb2(1):51-62. doi:10.1089/154065804322966315.

[33] Podolak I, Galanty A, Sobolewska D. Saponins as cytotoxic agents: a review. Phytochem Rev 2010;9(3):425-474. doi:10.1007/s11101 010-9183-z.

[34] Deer EL, González-Hernández J, Coursen JD, Shea JE, Ngatia J, Scaife $\mathrm{CL}$, et al. Phenotype and genotype of pancreatic cancer cell lines. Pancreas 2010;39(4):425-435. doi:10.1097/MPA.0b013e3181c15963.

[35] Ray RB, Raychoudhuri A, Steele R, Nerurkar P. Bitter melon (Momordica charantia) extract inhibits breast cancer cell proliferation by modulating cell cycle regulatory genes and promotes apoptosis. Cancer Res 2010;70(5):1925-1931. doi:10.1158/0008-5472.CAN-093438.

[36] Holland AJ, Cleveland DW. Beyond genetics: surprising determinants 
of cell fate in antitumor drugs. Cancer Cell 2008;14(2):103-105. doi:10.1016/j.ccr.2008.07.010.

[37] Rieder CL, Maiato H. Stuck in division or passing through: What happens when cells cannot satisfy the spindle assembly checkpoint. Dev Cell 2004;7(5):637-651. doi:10.1016/j.devcel.2004.09.002.

[38] Gascoigne KE, Taylor SS. Cancer Cells Display Profound Intra- and Interline Variation following Prolonged Exposure to Antimitotic Drugs. Cancer Cell 2008;14(2):111-122. doi:10.1016/j.ccr.2008.07.002.

[39] Pitchakarn P, Suzuki S, Ogawa K, Pompimon W, Takahashi S, Asamoto
$\mathrm{M}$, et al. Induction of $\mathrm{G} 1$ arrest and apoptosis in androgen-dependent human prostate cancer by Kuguacin J, a triterpenoid from Momordica charantia leaf. Cancer Lett 2011;306(2):142-150. doi:10.1016/j. canlet.2011.02.041.

[40] Thoennissen NH, Iwanski GB, Doan NB, Okamoto R, Lin P, et al. Cucurbitacin $B$ induces apoptosis by inhibition of the JAK/STAT pathway and potentiates antiproliferative effects of gemcitabine on pancreatic cancer cells. Cancer Res 2009;69(14):5876-5884. doi:10.1158/00085472.CAN-09-0536. 